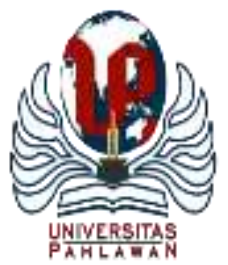

Edukatif : Jurnal Ilmu Pendidikan Volume 4 Nomor 1 Tahun 2022 Halm 1030 - 1042 EDUKATIF: JURNAL ILMU PENDIDIKAN

Research \& Learning in Education

https://edukatif.org/index.php/edukatif/index

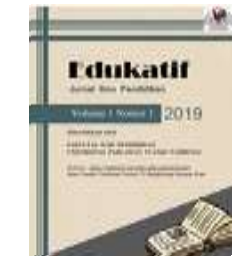

\title{
Studi Kebijakan Merdeka Belajar Kampus Merdeka (MBKM) dengan Menggunakan Pendekatan Kuantitatif dan Kualitatif
}

\author{
Ekaterina Setyawati $^{1 凶}$, Ira Mulyawati ${ }^{2}$, Soecahyadi $^{3}$ \\ Universitas Sahid Jakarta, Indonesia ${ }^{1,2,3}$ \\ E-mail : eka3na.5@gmail.com ${ }^{1}, \underline{\text { iramulyawati@gmail.com }}{ }^{2}$, soecahyadi31@gmail.com $^{3}$
}

\begin{abstract}
Abstrak
Merdeka Belajar Kampus Merdeka (MBKM) merupakan pembelajaran dengan memberikan Hak Belajar 3 semester diluar Program Studi yang bertujuan meningkatkan kompetensi lulusan. Studi terhadap kesiapan pihak institusi dalam melakukan implementasi dijadikan dasar strategi MBKM berjalan dengan baik. Salah satunya dari mahasiswa, bagaimana respon mereka terhadap pelaksanaannya. Penelitian dilakukan untuk melihat persepsi dan kesiapan mahasiswa mengenai MBKM untuk selanjutnya ditindak lanjuti merumuskan strategi tepat melalui Focus Group Discussion (FGD). Penelitian dilakukan dengan analisa deskriptif kuisioner yang diberikan kepada 313 orang mahasiswa Fakultas Teknik Universitas Sahid Jakarta (USahid) dan FGD yang dihadiri oleh para pakar Pendidikan dan dosen USahid. Hasil penelitian ini adalah pengetahuan mahasiswa mengenai adanya kebijakan program MBKM sudah sangat baik, tetapi untuk pengetahuan mahasiswa secara detail mengenai program MBKM masih ada yang rendah, kesiapan mahasiswa untuk menjadi bagian dalam kegiatan MBKM sudah cukup baik, dan penilaian mahasiswa mengenai manfaat program MBKM sudah sangat baik. Strategi yang diperoleh dari FGD diantaranya; perlu melakukan sosialisasi dan diskusi secara berkala melalui media-media online, baik dilakukan oleh Kemendikbud Ristek, Perguruan tingi, Fakultas dan Program studi; perlu adanya unit khusus di tingkat Universitas untuk melayani mahasiswa jika ada kendalan dalam menerapkan program MBKM dan perlu adanya panduan petunjuk teknis dan pelaksanaan MBKM di Program Studi.
\end{abstract}

Kata Kunci: Merdeka Belajar, Kampus Merdeka, USahid

\begin{abstract}
Merdeka Learning Campus Merdeka (MBKM) is a learning program that provides learning rights for 3 semesters outside the study program, aiming to improve graduates' competence. A study on the readiness of the institution to carry out implementation needs to be the basis for making the MBKM strategy run well. One of them is from students. The study was conducted to see students' perceptions and readiness regarding MBKM for further followup by formulating appropriate strategies through Focus Group Discussions (FGD). The study was conducted using descriptive analysis of questionnaires given to 313 students of the Faculty of Engineering, University of Sahid Jakarta (USahid), and FGDs attended by Education experts. The result is that students' knowledge about the MBKM program policy is excellent. However, it is still in the low range for detailed student knowledge. Students' readiness to take part in MBKM activities is quite good, and student assessments of the benefits of the MBKM program are Very good. The strategies obtained from the FGDs; periodic socialization and discussion through online media. Establish a particular unit to serve students if there are obstacles in implementing the program. There must be technical guidelines and instructions for implementing MBKM in the Study Program.
\end{abstract}

Keywords: Merdeka Learning, Merdeka Campus, USahid

Copyright (c) 2022 Ekaterina Setyawati, Ira Mulyawati, Soecahyadi

$\triangle$ Corresponding author:

Email : iramulyawati@gmail.com

DOI : https://doi.org/10.31004/edukatif.v4i1.2003

ISSN 2656-8063 (Media Cetak)

ISSN 2656-8071 (Media Online)

Edukatif : Jurnal Ilmu Pendidikan Vol 4 No 1 Tahun 2022 p-ISSN 2656-8063 e-ISSN 2656-8071 
1031 Studi Kebijakan Merdeka Belajar Kampus Merdeka (MBKM) dengan Menggunakan Pendekatan Kuantitatif dan Kualitatif - Ekaterina Setyawati, Ira Mulyawati, Soecahyadi

DOI: https://doi.org/10.31004/edukatif.v4i1.2003

\section{PENDAHULUAN}

Perguruan tinggi dihadapkan pada tantangan menghasilkan lulusan yang tangguh dalam menghadapi perubahan sosial, budaya, dunia kerja, dan teknologi yang semakin berkembang dengan pesat di era revolusi industri 4.0. Untuk itu, dibutuhkan kompetensi tambahan untuk memperkuat kompetensia mahasiswa sesuai dengan perkembangan yang ada. Saat ini, lulusan pendidikan tinggi dituntut untuk biisa siap dengan segela perubahan yang sangat cepat bukan hanya siap dengan dunia usaha dan dunia industri saja. Untuk itu, Kementerian Pendidikan dan Kebudayaan memberlakukan kebijakan baru di bidang pendidikan tinggi melalui program "Merdeka Belajar-Kampus Merdeka (MBKM)" yang saat ini mulai diterapkan oleh perguruan ("Gibah (Internal Initiative Movement Program For Grants): A Viable Implementation Of Mbkm Program In Science Major At Universitas Kristen Maranatha," n.d.; Hasil et al., 2021; Kodrat \& Kodrat, 2021; Rosmiati et al., 2021; Saehana et al., 2021).

Tujuan Hak Belajar 3 semester diluar Prodi adalah meningkatkan kompetensi lulusan, baik soft skills maupun hard skills, agar lebih siap dan relevan dengan kebutuhan zaman, menyiapkan lulusan sebagai pemimpin masa depan bangsa yang unggul dan berkepribadian. Program experiential learning dengan jalur yang fleksibel diharapkan akan dapat memfasilitasi mahasiswa mengembangkan potensinya sesuai dengan passion dan bakatnya. Perguruan Tinggi wajib memberikan hak bagi mahasiswanya untuk secara sukarela yang dapat diambil atau tidak, dapat mengambil sks di luar perguruan tinggi paling lama sebanyak 2 semester yang setara dengan 40 sks, ditambah lagi, dapat mengambil sks di prodi yang berbeda di PT yang sama sebanyak 1 semester yang setara dengan 20 sks (Puspitasari \& Nugroho, 2021; Sopiansyah et al., 2022)

Ada 5 kebijakan terkait paket Kampus Merdeka ini, yaitu a) sistem akreditasi perguruan tinggi; b) belajar di perguruan tinggi (hak belajar di luar program studi); c) kemudahan dalam membuka program studi baru; d) penerimaan mahasiswa baru; serta e) perubahan status menjadi perguruan Tinggi Negeri Badan Hukum. Ketentuan ini tidak berlaku untuk bidang Pendididikan dan Kesehatan (Fuadi \& Aswita, 2021).

Kunci keberhasilan implementasi kebijakan MBKM di sebuah perguruan tinggi adalah adanya keberanian dalam mengubah pola pikir dari pendekatan kurikulum berbasis konten yang kaku menjadi kurikulum berbasis capaian pembelajaran yang adaptif dan fleksibel untuk menyiapkan mahasiswa menjadi insan dewasa yang mampu berdikari. Program studi ditantang dalam mengembangkan kurikulum yang adaptif dan mampu menyesuaikan diri dengan perkembangan zaman yang semakin pesat tanpa keluar dari tujuan dalam menghasilkan lulusan sesuai dengan capaian pembelajaran yang telah ditentukan. Di samping itu, dalam implementasi kebijakan MBKM dibutuhkan adanya kolaborasi dan kerja sama dengan mitra ataupun pihak lain yang berkaitan dengan bidang keilmuannya dan turut serta dalam mendukung capaian pembelajaran yang diinginkan. Keadaan yang terjadi di lapangan dengan adanya kebijakan MBKM ini, program studi mengalami kesulitan dalam mengembangkan kurikulum dan implementasinya (Nona et al., 2022; Pembelajaran et al., n.d.).

Berdasarkan hal tersebut, maka perlu dilakukan studi kesiapan oleh pihak institusi dalam melakukan implementasinya dan juga persepsi. Salah satunya, dari mahasiswa dalam mengimplementasikan kegiatan ini (Denny Pareira Meke et al., 2022). Penelitian dilakukan untuk melihat kesiapan para mahasiswa dari sudut pandang mahasiswa mengenai program MBKM.

Berbagai penelitian kebijakan mengenai program MBKM telah dilakukan menggunakan metode deskriptif kuantitatif. Metode deskriptif kuantitatif yaitu dengan melakukan penyebaran kuisioner kepada mahasiswa. Analisis data yang dilakukan secara deskriptif (Denny Pareira Meke et al., 2022; Laga et al., 2022; Sulistiyani et al., 2022). Selain itu, penelitian kebijakan mengenai program MBKM dilakukan juga dengan menggunakan metode kualitatif. Penelitian kualitatif dengan melakukan wawancara pada pihak-pihak yang berkenaan langsung dengan kebijakan MBKM, Focus Group Discussion (FGD) (Baert et al., 2021; Puspitasari \& Nugroho, 2021; View of Dampak Kebijakan MBKM Pada Kesiapan Sumber Daya Manusia Dan 
1032 Studi Kebijakan Merdeka Belajar Kampus Merdeka (MBKM) dengan Menggunakan Pendekatan Kuantitatif dan Kualitatif - Ekaterina Setyawati, Ira Mulyawati, Soecahyadi

DOI: https://doi.org/10.31004/edukatif.v4i1.2003

Fasilitas Fakultas Hukum Usahid Jakarta, n.d.; View of Penguatan Pemahaman Dan Orientasi Kurikulum Kampus Merdeka Dalam Menyambut Merdeka Belajar-Kampus Merdeka, n.d.)

Berdasarkan penelitian-penelitian diatas belum ada penelitian mengenai kebijakan mengenai program MBKM yang memadukan dua metode, dalam hal ini metode kuantitatif dan kualitatif. Sehingga pada penelitian ini dilakukan penggabungan dua metode yaitu metode kuantitatif dan kualitatif. Metode Kuantitatif yaitu dengan penyebaran kuisioner kepada mahasiswa. Analisis data yang dilakukan secara deskriptif. Metode Kualitatif dengan dilakukan Focus Group Discussion (FGD) untuk eksplorasi hasil dan merancang usulan strategi.

\section{METODE PENELITIAN}

Pada penelitian ini terdapat dua tahapan, tahap pertama menggunakan desain penelitian survei crosssectional (Septiani \& Kejora, 2021), dengan pengumpulan data kuantitatif. Teknik pemilihan sampel menggunakan stratified random sampling. Jumlah sampel 313 mahasiswa Fakultas Teknik Universitas Sahid Jakarta, cara pengambilan data dengan penyebaran kuisioner kepada mahasiswa Fakultas Teknik Universitas Sahid Jakarta melalui google form. Analisis data yang dilakukan secara deskriptif.

Penelitian deskriptif kuantitatif merupakan suatu penelitian yang mempunyai tujuan untuk mendeskripsikan suatu fenomena, peristiwa, gejala, dan kejadian yang terjadi secara faktual, sistematis, serta akurat. Selain angket, digunakan juga pedoman wawancara agar hasil penelitian (Priyono, 2016).

Pertanyaan-pertanyaan yang diberikan kepada mahasiswa, diantaranya mengenai hal-hal berikut ini:

1. Pengetahuan tentang Kebijakam Merdeka Belajarar Kampus Merdeka (MBKM)

2. Pengetahuan tentang jumlah semester dan sks yang dapat disetarakan dalam MBKM

3. Pengetahuan tentang dokumen kurikulum panduan dan prosedur operasional untuk mengikuti kegiatan MBKM yang ada di Universitas

4. Pengetahuan mahasiswa mengenai apa saja yang perlu dipersiapkan agar implementasi MBKM berjalan optimal

5. Kesiapan mahasiswa untuk menjadi bagian dalam kegiatan MBKM

6. Tanggapan mahasiswa mengenai kompetensi tambahan seperi ketrampilan dalam menyelesaikan permasalahan nyata yang kompleks, ketrampilan dalam menganalisis etika profesi dll

7. Tanggapan mahasiswa mengenai belajar di Program studi lain akan memperluas prespektif dan memberikan kompetensi tambahan yang dibutuhkan

8. Tangggapan mahasiswa mengenai peningkatan soft skill yang diperoleh setelah mengikuti kegiatan MBKM dalam pengembangan kompetensi/ ketrampilan sebagai bekal bekerja setelah lulus.

Tahap kedua pada penelitian ini adalah Focus Group Discussion (FGD) untuk eksplorasi hasil dan merancang usulan strategi (Afiyanti, 2008; Baert et al., 2021; Fatmawati, 2021; Puspitasari \& Nugroho, 2021; View of Dampak Kebijakan MBKM Pada Kesiapan Sumber Daya Manusia Dan Fasilitas Fakultas Hukum Usahid Jakarta, n.d.; View of Penguatan Pemahaman Dan Orientasi Kurikulum Kampus Merdeka Dalam Menyambut Merdeka Belajar-Kampus Merdeka, N.D.; View Of Rancangan Solusi Pengelolaan Sampah Dengan Konsep Focus Group Discussion (Fgd) Penta Helix Di Kabupaten Garut, n.d.; Widiyati, 2019). Untuk mengatasi kendala-kendala diatas diperlukan strategi-strategi yang tepat, maka dari itu Fakultas Teknik Universitas Sahid Jakarta menyelenggarakan Focus group discussion (FGD) pada tanggal 21 Desember 2021. FGD ini dihadiri oleh para pakar Pendidikan dan dosen-dosen Universitas Sahid Jakarta.

Penelitian ini menggunakan metode kualitatif dengan pendekatan focus group discussion (FGD) dimana para pakar Pendidikan dan dosen-dosen Universitas Sahid Jakarta dapat menyampaikan apa yang telah dilakukan dalam program MBKM dan apa solusi yang diberikan untuk menyelesaikan dalam menjalankan program MBKM, sehingga masing-masing dapat saling mengetahui apa yang disampaikan satu sama lainnya sehingga dapat mendapatkan strategi-strategi yang tepat untuk menjalankan program MBKM. 
1033 Studi Kebijakan Merdeka Belajar Kampus Merdeka (MBKM) dengan Menggunakan Pendekatan Kuantitatif dan Kualitatif - Ekaterina Setyawati, Ira Mulyawati, Soecahyadi

DOI: https://doi.org/10.31004/edukatif.v4i1.2003

Data selanjutnya dibuat transkrip dan dianalisis menggunakan teknik analisis reduksi data. Triangulasi sumber dilakukan dengan cara mengkonfirmasi temuan pada ketua penyelenggara kegiatan sekaligus inisiator FGD.

Hasil penelitian ini akan digunakan sebagai adaptasi atas kajian kegiatan merdeka belajar kampus merdeka tentang perencanaan, proses pembelajaran, penilaian dan evaluasi pembelajaran. Lebih lanjut, hasil penelitian ini akan digunakan untuk melihat kesesuaian terhadap kurikulum program studi yang telah ada serta menjadi acuan untuk merancang proses pembelajaran serta kerjasama akademik yang relevan (Baharuddin, 2021).

\section{HASIL DAN PEMBAHASAN PENELITIAN}

Setelah dilakukan penyebaran kuesioner kemudian dilakukan pengolahan data dengan menyajikan data dalam bentuk grafik agar mudah difahami. Hasil kuesioner disajikan pada Grafik 1 sampai dengan 8.

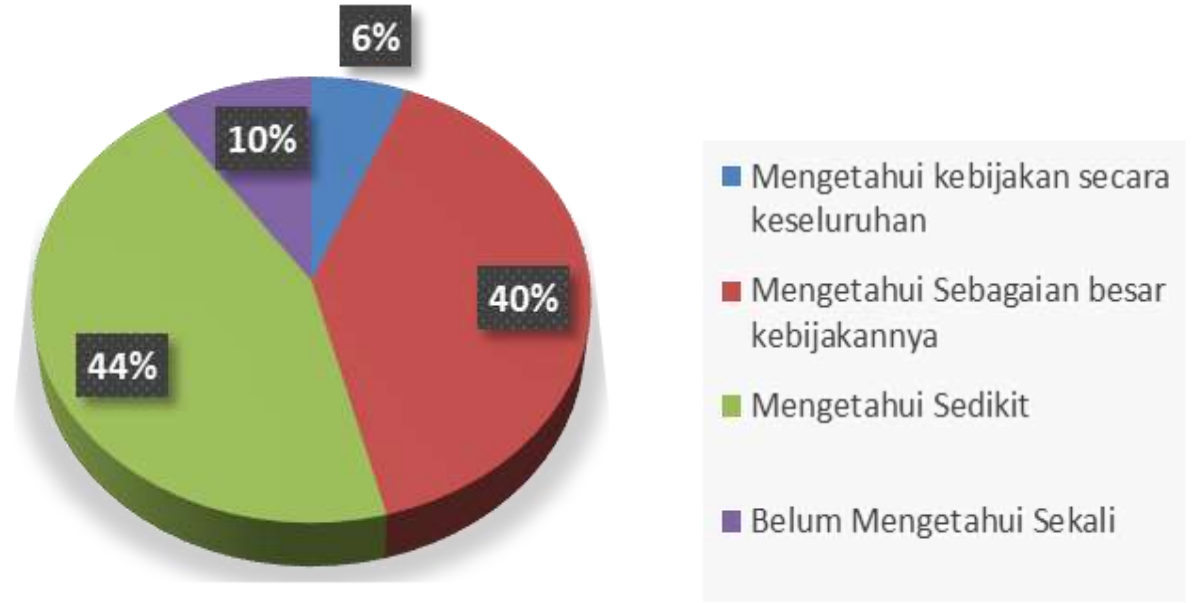

\section{Grafik 1. Pengetahuan mahasiswa tentang kebijakan merdeka belajar kampus merdeka (MBKM)}

Pengetahuan mahasiswa tentang sebagian besar kebijakan merdeka belajar kampus merdeka (MBKM) sudah cukup baik, hal ini dapat dilihat presentase mahasiswa yang mengetahui sebagian besar kebijakan tentang MBKM yaitu 40\% Grafik 1. Presentase ini lebih tinggi dibandingkan dengan hasil penelitian lain (Denny Pareira Meke et al., 2022) yaitu sebesar 15.6\% dan (Laga et al., 2022) yaitu sebesar 18\%. Pengetahuan mahasiswa yang cukup baik mengenai kebijakan merdeka belajar kampus merdeka (MBKM) ini dikarenakan sosialisasi yang masif oleh Kemendikbud Ristek, Pihak Universitas, Fakultas dan Prgram Studi (Prodi).

Kendati demikian, presentase yang mengetahui sedikit kebijakan Merdeka Belajar Kampus Merdeka (MBKM) masih tinggi yaitu $44 \%$ dan masih ada mahasiswa yang tidak mengetahui sama sekali tentang kebijakan MBKM dengan presentase sebesar $10 \%$. Hal ini sejalan dengan penelitian lain (Denny Pareira Meke et al., 2022) presentase yang mengetahui sedikit kebijakan MBKM yaitu sebesar $71 \%$ dan yang tidak mengetahui sama sekali 6\%. Berdasarkan penelitian (Laga et al., 2022) presentase yang mengetahui sedikit kebijakan MBKM yaitu sebesar $57 \%$ dan yang belum mengetahui sama sekali sebesar $8 \%$. Hal ini dikarenakan tidak adanya sosialiasasi lanjutan yang terjadwal untuk membahasa lebih mendalam mengenai kebijakan Merdeka Belajar Kampus Merdeka (MBKM) ini, sosiasilasi sudah dilakukan beberapa kali sehingga Sebagian besar besar mahasiswa mengetahui kebijakan Merdeka Belajar Kampus Merdeka (MBKM). Tetapi, mahasiswa tidak mengetahui secara detail dan menyeluruh mengenai kebijakan ini. Oleh karena itu, pengetahuan mahasiswa tentang kebijakan merdeka belajar kampus merdeka masih perlu ditingkatkan lagi, sehingga diperlukan stretegi untuk meningkatkan pengetahuan mahasiswa menjadi lebih luas dan mendalam mengenai program Merdeka Belajar Kampus Merdeka (MBKM) ini. 
1034 Studi Kebijakan Merdeka Belajar Kampus Merdeka (MBKM) dengan Menggunakan Pendekatan Kuantitatif dan Kualitatif-Ekaterina Setyawati, Ira Mulyawati, Soecahyadi

DOI: https://doi.org/10.31004/edukatif.v4i1.2003

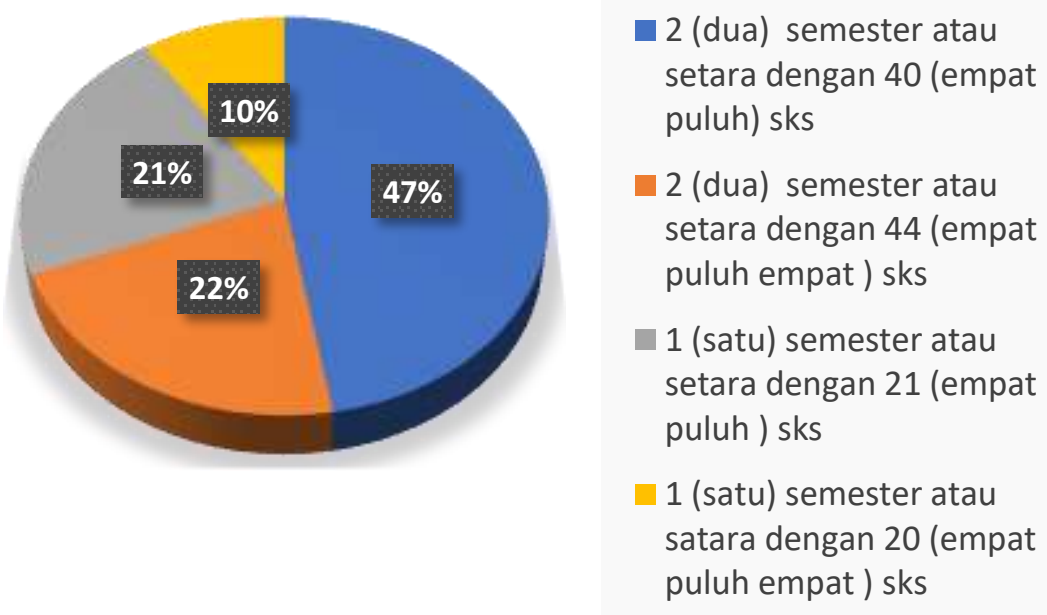

\section{Grafik 2. Pengetahuan mahasiswa mengenai jumlah semester dan sks yang dapat disetarakan dengan bentuk kegiatan Merdeka Belajar Kampus Merdeka (MBKM) di luar Perguruan Tingginya}

Pengetahuan mahasiswa tentang Sebagian besar kebijakan merdeka belajar kampus merdeka (MBKM) sudah baik, hal ini sejalan dengan pengetahuan mahasiswa mengenai jumlah semester dan sks yang dapat disetarakan dengan bentuk kegiatan Merdeka Belajar Kampus Merdeka (MBKM) di luar Perguruan Tinggi. Presentase mahasiswa dengan jawaban yang tepat mengenai jumlah semester dan sks yang dapat disetarakan, yaitu sekitar 47\%. Presentase ini lebih tinggi dibandingkan dengan hasil yang diperoleh (Denny Pareira Meke et al., 2022) yaitu sebesar 7.8\% mahasiswa yang menjawab sesuai dengan ketentuan 40 sks dan (Laga et al., 2022) yaitu sebesar $29,41 \%$.

Selanjutnya peneliti ingin mengetahui bagaimana kesiapan mahasiswa untuk menjadi bagian dalam kegiatan MBKM. Sehingga butir pertanyaan selanjutnya yaitu apakah mahasiswa sudah menyiapkan diri untuk menjadi bagian dalam kegiatan MBKM. Kesiapan mahasiswa untuk menjadi bagian dalam kegiatan MBKM sudah cukup baik. Hal ini bisa dilihat dari presentase jumlah mahasiswa yang sudah mempersiapkan diri ikut serta dan menjadi ingin menjadi bagian dari MBKM yaitu sekitar 54\%, yang belum mempersiapkan $40 \%$ dan yang tidak berminat 6\%. Hal ini sejalan dengan penelitian (Laga et al., 2022) yaitu kesiapan mahasiswa untuk menjadi bagian dalam kegiatan Merdeka Belajar-Kampus Merdeka (MBKM) sebesar 63 persen dan 35 persen belum siap menghadapi kebijakan Merdeka Belajar-Kampus Merdeka (MBKM) dan 1 persen tidak berminat dalam mengikuti kebijakan Merdeka Belajar-Kampus Merdeka (MBKM).

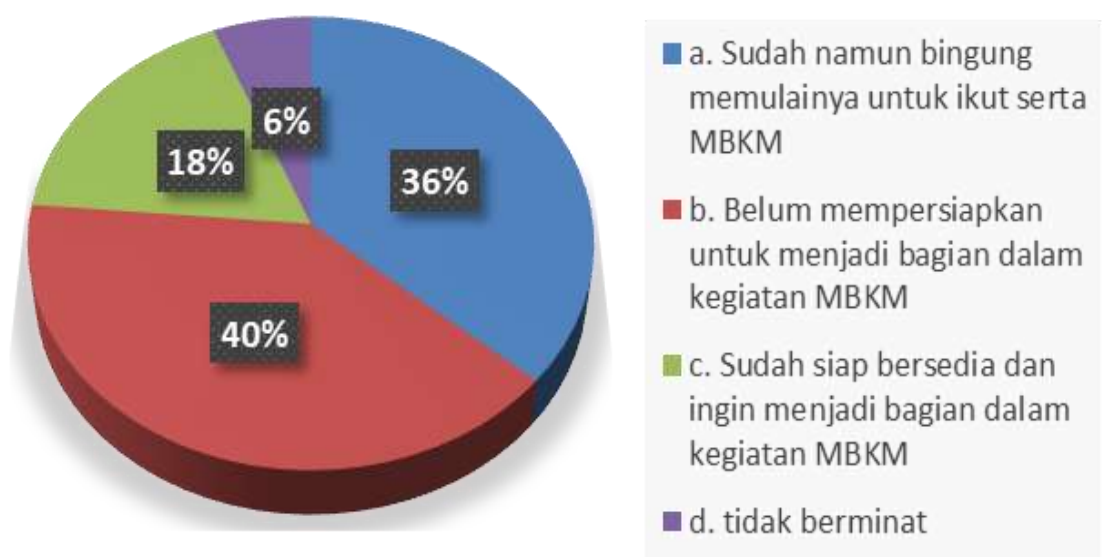

Grafik 3. Kesiapan mahasiswa untuk menjadi bagian dalam kegiatan MBKM 
1035 Studi Kebijakan Merdeka Belajar Kampus Merdeka (MBKM) dengan Menggunakan Pendekatan Kuantitatif dan Kualitatif - Ekaterina Setyawati, Ira Mulyawati, Soecahyadi

DOI: https://doi.org/10.31004/edukatif.v4i1.2003

Kendati demikian perlu menjadi perhatian adalah bahwa mahasiswa yang sudah mempersiapkan dan bingung bagaimana memulai keiikutsertaannya harus segera diberikan perhatian agar semangatnya untuk mengikuti program MBKM tidak surut. Begitu pula dengan mahasiswa yang belum sama sekali mempersiapkan dan tidak berminat sama sekali terhadap program MBKM, diperlukan strategi khusus agar motivasinya meningkat untuk mengituti program MBKM. Masih tinginya presentase mahasiswa yang belum mempersiapkan untuk menjadi bagian dalam kegiatan MBKM, hal ini dimungkinkan karena mahasiswa beranggapan bahwa program belajar diluar prodi akan menyebabkan lamanya masa studi, selain itu mahasiswa beranggapan bahwa pada masa pandemic Covid-19 ini akan kesulitan untuk mencari tempat untuk magang industry.

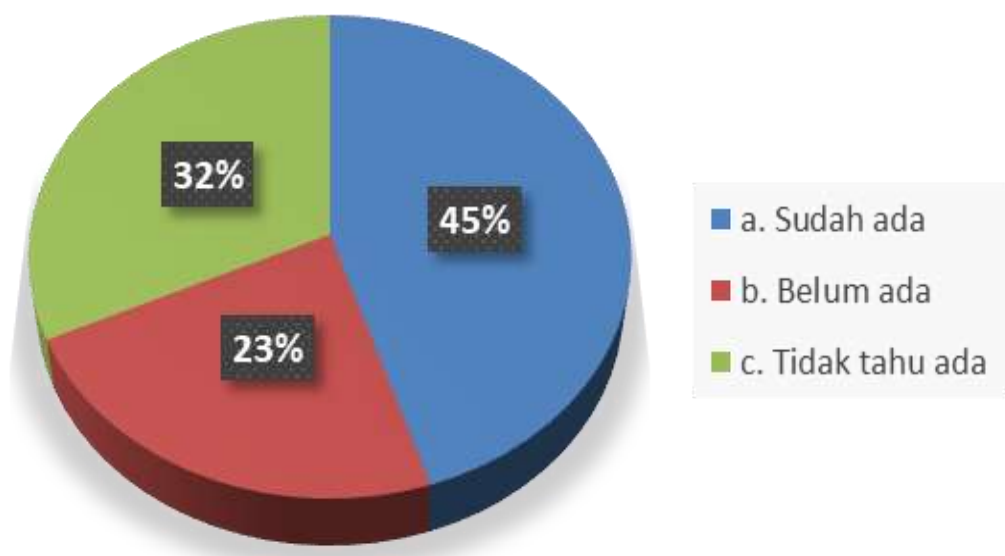

\section{Grafik 4. Pengetahuan mahasiswa tentang dokumen kurikulum panduan dan prosedur operasional untuk mengikuti kegiatan MBKM di Program Studi}

Selanjutnya peneliti ingin mengetahui lebih dalam tentang pengetahuan mahasiswa mengenai kebijakan MBKM. Oleh karena itu butir pertanyaan selanjutnya adalah tentang dokumen kurikulum panduan dan prosedur operasional untuk mengikuti kegiatan MBKM di Program Studi. Hasilnya sebesar 45\% mahasiswa telah mengetahui ketersediaan dokumen tersebut, $23 \%$ mahasiswa belum mengetahui dan $32 \%$ mahasiswa tidak mengetahui sama sekali mengenai program Merdeka Belajar-Kampus Merdeka (MBKM). Hal ini sejalan dengan hasil penelitian yang dilakukan oleh (Laga et al., 2022) yaitu 44 persen mahasiswa telah mengetahui ketersediaan dokumen tersebut, 27,41 persen mahasiswa belum mengetahui dan 28 persen mahasiswa tidak mengetahui sama sekali mengenai program Merdeka Belajar-Kampus Merdeka (MBKM).

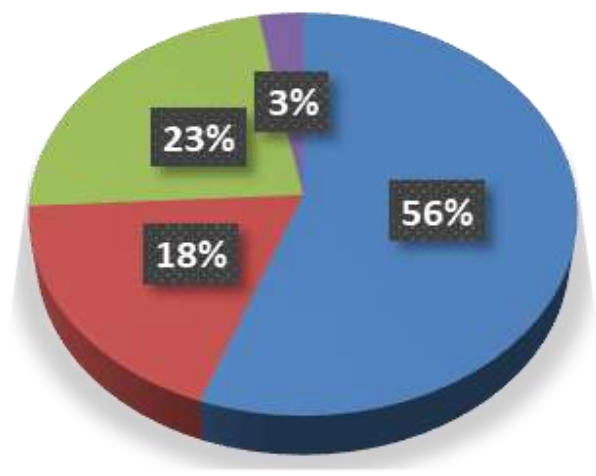

a. Mempelajari panduan
MBKM dan Kurikulum yang
memfasilitasi MBKM
b. Mengikuti seleksi kegiatan
dan menyiapkan syarat-
syarat yang dibutuhkan
c. Proaktif dalam
mempersiapkan kegiatan
pembelajaran yang sesuai
d. Lainnya

\section{Grafik 5. Pengetahuan mahasiswa terhadap hal-hal yang perlu dipersiapkan oleh mahasiswa agar implementasi MBKM berjalan optimal}

Pada penelitian ini ingin diketahui juga mengenai kesiapan mahasiswa dalam menerapkan program MBKM. Untuk itu, butir pertanyaan selanjutnya yaitu tentang pengetahuan mahasiswa terhadap hal-hal yang 
1036 Studi Kebijakan Merdeka Belajar Kampus Merdeka (MBKM) dengan Menggunakan Pendekatan Kuantitatif dan Kualitatif - Ekaterina Setyawati, Ira Mulyawati, Soecahyadi

DOI: https://doi.org/10.31004/edukatif.v4i1.2003

perlu dipersiapkan oleh mahasiswa agar implementasi MBKM berjalan optimal dan hasilnya sudah cukup baik. Hal ini, dapat dilihat dari presentase pengetahuan mahasiswa yang mempelajari panduan MBKM dan kurikulun yang memfasilitasi MBKM yaitu 56\%. Hal ini sejalan dengan penelitian (Laga et al., 2022) yaitu sebesar 57 persen mahasiswa perlu mempelajari panduan Merdeka Belajar-Kampus Merdeka (MBKM) dan kurikulum yang memfasilitasi Merdeka Belajar-Kampus Merdeka.

Pengetahuan mahasiswa mengenai kegiatan MBKM yang detail dan mendalam masih pada rentang ratarata dengan presentase antara $40 \%-56 \%$. Hal ini disebabkan oleh beberapa hal diantaranya:

1. tidak ada sosialisasi secara berkala atau terjdawal secara kontinu selama kurun waktu tertentu hingga mahasiswa faham sepenuhnya mengenai dokumen kurikulum, panduan operasional MBKM ;

2. kurangnya durasi sosialisasi mengenai kegiatan MBKM;

3. tidak adanya unit khusus untuk melayani diskusi secara detail dan mendalam dengan mahasiswa terkait MBKM;

4. belum adanya pedoman petunjuk pelaksanaan dan petunjuk Teknis di Tingkat Program studi yang mudah diakses baik oleh dosen maupun mahasiswa.

Selanjutnya peneliti ingin mengetahui bagaimana penilaian mahasiswa terhadap program Merdeka Belajar-Kampus Merdeka (MBKM). Untuk itu butir pertanyaan selanjutnya akan seputar penilaian mahasiswa terhadap kegiatan pembelajaran di luar kampus akan memberikan kompetensi tambahan seperti keterampilan dalam menyelesaikan permasalahan nyata yang kompleks, ketrampilan dalam menganalisis etika profesi dll, kemudian penilaian mahasiswa terhadap belajar di Program studi lain akan memperluas prespektif dan memberikan kompetensi tambahan yang dibutuhkan dan penilaian mahasiswa terhadap manfaat mengikuti MBKM dalam pengembangan kompetensi / ketrampilan sebagai bekal bekerja setelah lulus.

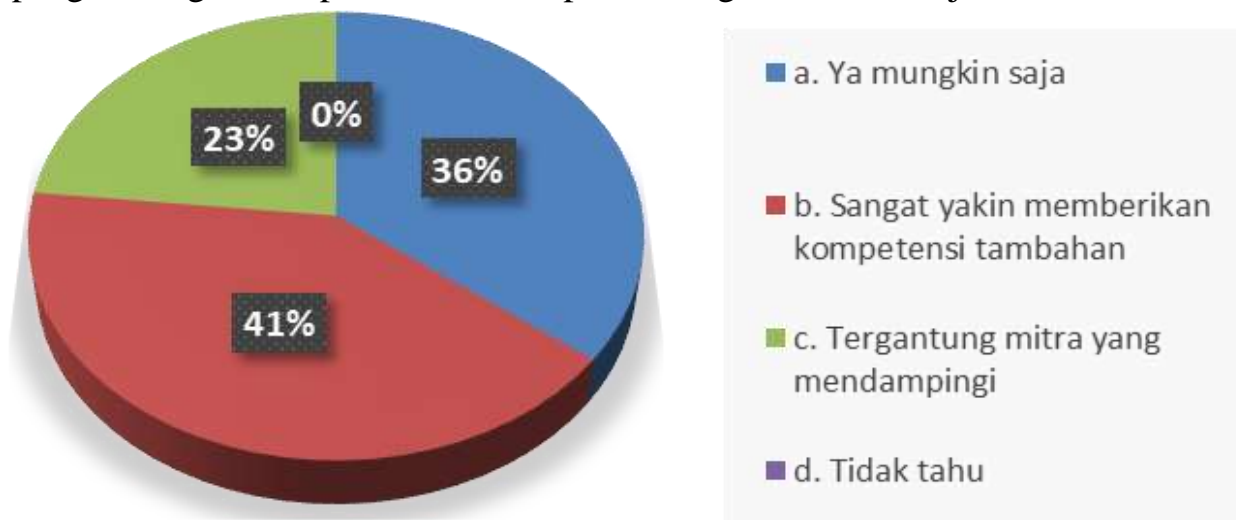

\section{Grafik 6. Penilaian mahasiswa terhadap kegiatan pembelajaran di luar kampus akan memberikan kompetensi tambahan seperti keterampilan dalam menyelesaikan permasalahan nyata yang kompleks, ketrampilan dalam menganalisis etika profesi dll}

Penilaian mahasiswa terhadap kegiatan pembelajaran di luar kampus akan memberikan kompetensi tambahan seperti keterampilan dalam menyelesaikan permasalahan nyata yang kompleks, ketrampilan dalam menganalisis etika profesi dll sudah baik. Hal ini ditandai oleh tingginya presentasi penilaian mahasiswa yaitu 77\%, sedangkan sisanya, masih ragu-ragu dan tidak tahu. Hal ini sejalan dengan penelitian (Laga et al., 2022) Hasil survey menunjukan bahwa 74,5 persen yakin akan ada peningkataan, 22 menjawab mungkin dan 3,5 persen tidak tahu dampak peningkatan kompetensi tambahan kegiatan pembelajaran diluar kampus.

Presentase Penilaian mahasiswa terhadap kegiatan pembelajaran di luar kampus akan memberikan kompetensi tambahan yang masih tinggi pada pilihan ragu-ragu dan tergantung mitra dimungkinkan karena mahasiswa beranggapan pada situasi pandemic Covid-19 ini akan kesulitan untuk mendapatkan mitra yang seusai dengan minat kompentensi tambahan yang ingin mahasiswa miliki. Sehingga mahasiswa masih ragiragu. 
1037 Studi Kebijakan Merdeka Belajar Kampus Merdeka (MBKM) dengan Menggunakan Pendekatan Kuantitatif dan Kualitatif - Ekaterina Setyawati, Ira Mulyawati, Soecahyadi

DOI: https://doi.org/10.31004/edukatif.v4i1.2003

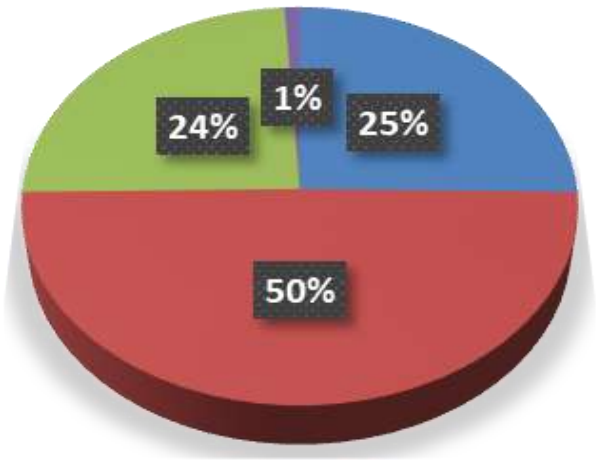

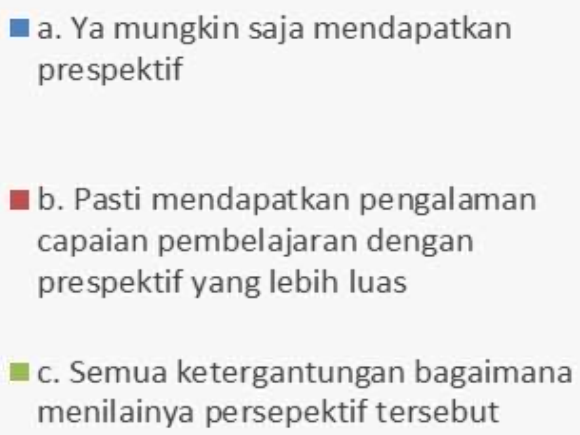

d. Tidak tahu

\section{Grafik 7. Penilaian mahasiswa terhadap belajar di Program studi lain akan memperluas prespektif dan memberikan kompetensi tambahan yang dibutuhkan}

Penilaian mahasiswa terhadap belajar di Program studi lain akan memperluas prespektif dan memberikan kompetensi tambahan yang dibutuhkan sudah baik. Hal ini dapat dilihat dari tingginya presentase penilaian mahasiswa yaitu $74 \%$. Namun demikian, mahasiswa yang masih ragu-ragu dan tidak tahu mengenai belajar di Program studi lain akan memperluas prespektif dan memberikan kompetensi tambahan, memiliki presentasi yang masih cukup tinggi yaitu $25 \%$, sehingga diperkukan strategi untuk meningkatkan motivasi mahasiswa mengenai program MBKM. Hal ini sejalan dengan penelitian yang dilakukan oleh (Laga et al., 2022) yaitu perspektif peningkatan wawasan dengan belajar di program studi lain dan peningkatan kompetensi tambahan sebanyak 65,5 persen mahasiswa menjawab ya akan ada peningkatan dan 31 persen menjawab mungkin sedangkan 3 persen tidak tahu.

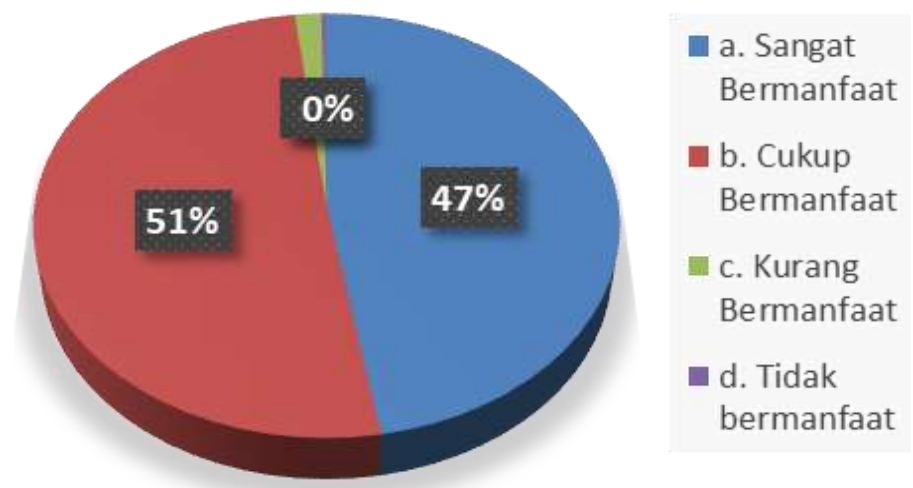

\section{Grafik 8. Penilaian mahasiswa terhadap manfaat mengikuti MBKM dalam pengembangan kompetensi/ketrampilan sebagai bekal bekerja setelah lulus}

Penilaian mahasiswa terhadap manfaat mengikuti MBKM dalam pengembangan kompetensi / ketrampilan sebagai bekal bekerja setelah lulus sudah sangat baik. Hal ini, dapat dilihat dari dari tingginya penilaian mahasiswa terkait manfaat program MBKM yaitu 98\%. Walaupun demikian, masih terdapat mahasiswa yang menilai bahwa program MBKM tersebut kurang bermanfaat dan tidak bermanfaat. Untuk itu, perlu strategi untuk meningkatkan penilaian mahasiswa menjadi 100\%. Hal ini sejalan dengan penelitian yang dilakukan oleh (Laga et al., 2022) Mahasiswa program studi manajemen merasakan manfaat Merdeka BelajarKampus Merdeka (MBKM) sebagai bekal setelah lulus sebesar 70 persen menjawab sangat bermanfaat, 27 persen menjawab cukup bermanfaat dan 3 persen merasa kurang bermanfaat.

Untuk mengatasi kendala-kendala diatas diperlukan strategi-strategi yang tepat, maka dari itu Fakultas Teknik Universitas Sahid Jakarta menyelenggarakan Focus group discussion (FGD) pada tanggal 21 
1038 Studi Kebijakan Merdeka Belajar Kampus Merdeka (MBKM) dengan Menggunakan Pendekatan Kuantitatif dan Kualitatif - Ekaterina Setyawati, Ira Mulyawati, Soecahyadi

DOI: https://doi.org/10.31004/edukatif.v4i1.2003

Desember 2021 Gambar 1. FGD ini dihadiri oleh para pakar Pendidikan dan dosen-dosen Universitas Sahid Jakarta sebanyak 20 orang.

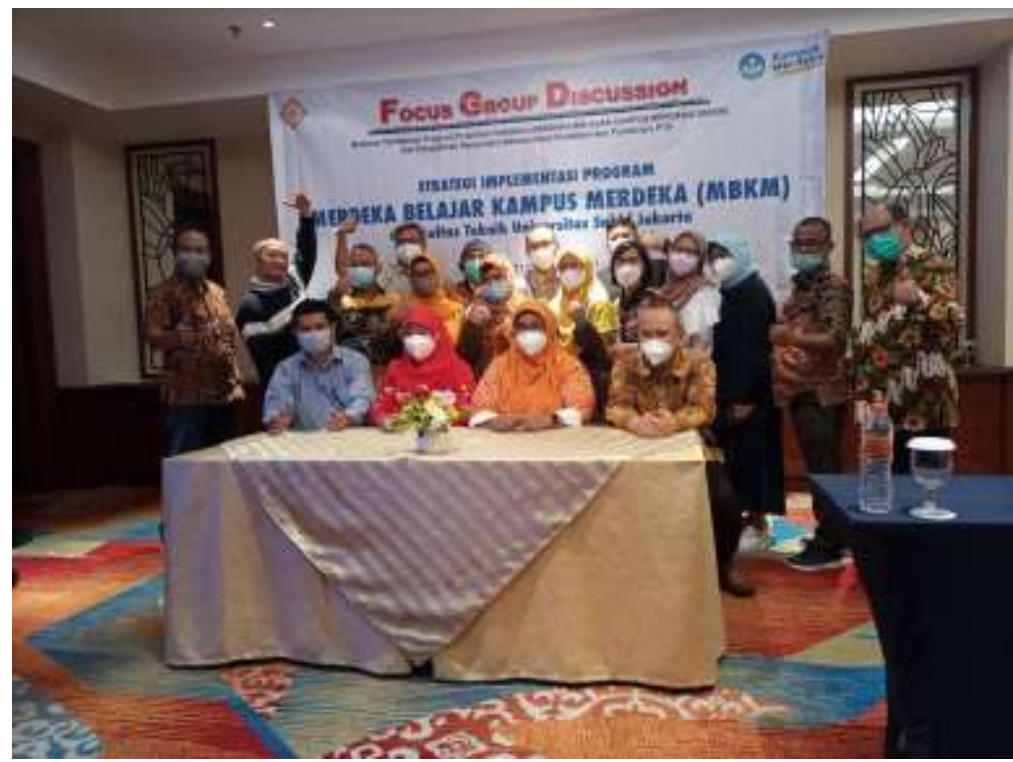

\section{Gambar 1. Focus group discussion (FGD) strategi implementasi program MBKM Fakultas Teknik} USahid

Focus group discussion (FGD) dilakukan untuk mendapatkan hasil yang komprehensif. FGD ini bertujuan mengeksplorasi strategi-strategi yang tepat untuk mengatasi berbagai kendala dalam mengimplementasikan kebijakan MBKM.

Memperlancar pelaksanaan MBKM di Universitas Sahid Jakarta, pihak universitas telah membentuk Tim MBKM Usahid serta menyusun Buku Pedomam MBKM Usahid. Melalui Buku Pedoman MBKM tersebut setiap fakultas menginisiasi setiap prodi untuk menyusun kurikulum prodi yang berbasis MBKM sebab pihak universitas ataupun program studi wajib memberikan hak belajar 3 semester di luar program studi. Fakultas Teknik Universitas Sahid Jakarta pada angkatan pertama yang melaksanakan MBKM yaitu pada tahun ajaran 2020/2021. Ada dua prodi yaitu Prodi Teknik Lingkungan dan Prodi Teknik Indusri. Penyusunan kurikulum dipersiapkan dengan membentuk tim work serta melakukan analisis kebutuhan, FGD dan workshop kurikulum. Fakultas Teknik telah membuat kurikulum sesuai MBKM. Kurikulum ini kemudian disosialisasikan kepada dosen dan mahasiswa. Sosialisasi ini dilaksanakan via zoom, melalui kuliah umum serta via whatsapp. Pelaksanaan hak belajar 3 semester di luar program studi di Fakultas Teknik Usahid, pada tahun pertama melaksanakan magang industri. Persiapan yang dilakukan oleh Program Studi Teknik Lingkungan adalah bagaimana menyiapkan mahasiswa untuk mengikuti program MBKM, kemudian kesiapan berupa sumber daya manusia, sumber daya sarana dan sumber daya informasi. Sumber daya manusia adalah para dosen atau tim work, Sumber daya sarana yakni yakni adanya google form yang disediakan untuk mendaftar. Serta sumber daya informasi yakni adanya SOP alur pendaftaran setiap program MBKM yang ingin diikuti.

Kultur Belajar yang Inovatif, Variatif dan Sesuai Kebutuhan Mahasiswa Kultur belajar yang inovatif dan variatif adalah suatu proses pembelajaran yang dirancang berbeda dari keadaan sebelumnya atau merupakan suatu proses pembelajaran baru untuk memotivasi dan meningkatkan hasil belajar mahasiswa dalam belajar. Secara umum, pembelajaran inovatif dan variatif adalah sebagai berikut: 1) Mahasiswa terlibat dalam berbagi kegiatan yang mengembangkan pemahaman dan kemampuan mereka. 2) Dosen menggunakan berbagai alat bantu dan berbagai cara dalam membangkitkan semangat, termasuk menggunakan lingkungan sebagai sumber belajar untuk menjadikan pembelajaran menarik, menyenangkan dan cocok bagi mahasiswa. 3) Dosen mengatur kelas dengan mengajar yang lebih kooperatif dan interaktif, termasuk cara belajar 
1039 Studi Kebijakan Merdeka Belajar Kampus Merdeka (MBKM) dengan Menggunakan Pendekatan Kuantitatif dan Kualitatif - Ekaterina Setyawati, Ira Mulyawati, Soecahyadi

DOI: https://doi.org/10.31004/edukatif.v4i1.2003

kelompok. 4) Dosen menerapkan cara mengajar yang lebih kooperatif dan interaktif, termasuk cara belajar kelompok. 5) Dosen mendorong mahasiswa untuk menemukan caranya sendiri dalam memecahkan masalah, untuk mengungkapkan gagasannya (Asiah, 2021).

Berdasarkan hasil penelitian sebelumnya (Asiah, 2021), kultur belajar yang inovatif dan variatif sesuai dengan kebutuhan mahasiswa pada program Merdeka Belajar-Kampus Merdeka dinilai telah ada unsur inovatif dan variatifnya, karena pembelajaran dapat dilakukan dimana saja secara daring, Mahasiswa dapat memilih sesuai dengan minatnya serta mencari pengalaman kegiatan belajar di luar program studi yang kemudian dapat dikonversi menjadi beberapa SKS. Mahasiswa dibebaskan (merdeka) memilih bentuk pembelajaran yang ingin diikuti. Pembelajaran inovatif dan variatif pada program MBKM yang telah dijalankan di Fakultas Teknik, Prodi Teknik Lingkungan dan Teknik Industri dalam hasil penelitian unsur inovatif dalam pembelajaran telah memenuhi namun dalam variatifnya masih perlu ditingkatkan. Inovatifnya yaitu Mahasiswa dapat belajar di lingkungan manapun, pada pertukaran Mahasiswa serta mahasiswa memperoleh fokus ilmu yang berbeda. Pada program magang dan kewirausahaan mahasiswa dapat belajar di kantor atau perusahaan yang kemudian dapat dikonversi menjadi beberapa SKS. Pada hasil peneltian pertukaran Mahasiswa antar Prodi Teknik Lingkungan dan Teknik Industri pembelajaran inovatif yang dilakukan adalah penyelesaian kasus, serta diskusi antar mahasiswa yang tetap dosen sebagai fasilitator dalam belajar dan diskusi, tapi Mahasiswa yang tetap dituntut lebih aktif. Sementara variatif dalam pembelajaran dinilai masih perlu ditingkatkan karena mahasiswa merasa kebanyakan pembelajaran yang diberikan hanyalah pemberian materi (jurnal atau video) lalu ditugaskan untuk membuat ulasannya. Masih kurang sekali diskusi secara langsungnya, serta media pembelajaran yang digunakan hampir sama. Pada program magang inovatif dan variatifnya yang didapatkan oleh mahasiswa adalah mahasiswa merasa memperoleh pengalaman baru bagaimana bekerja langsung. Mahasiswa merasakan perbedaan pada teori dan praktik. Program Kewirausahaan pada hasil penelitian tentunya mahasiswa didorong untuk membuat produk baru yang menarik serta beragam. Hasil penelitian yang diperoleh bahwa program Merdeka Belajar-Kampus Merdeka ini telah sesuai dengan kebutuhan mahasiswa hanya saja dalam pelaksanaannya masih perlu ditingkatkan agar hal-hal yang dibutuhkan mahasiswa seperti memperoleh fokus ilmu yang berbeda secara maksimal, pengalaman yang luas serta kemampuan kewirausahaan betul-betul dapat diperoleh dengan baik oleh mahasiswa.

Kendala Pelaksanaan Merdeka Belajar Kampus Merdeka di Fakultas Teknik Universitas Sahid Jakarta yang terdiri dari dua program studi yaitu Teknik Lingkungan dan Teknik Industri Pelaksanaan Kebijakan Merdeka Belajar Kampus Merdeka tentunya ada beberapa kendala yang dihadapi. Program studi Teknik Lingkungan dan Teknik industri menjadi program studi yang pertama kali melaksanakan kebijakan MBKM di Universitas Sahid tentunya program studi, dosen dan mahasiswa selaku pelaksana mengalami berbagai kendala. a. Kendala Program Studi Kendala yang dialami Prodi Teknik Lingkungan dan Teknik Industri dalam pelaksanaan kebijakan Merdeka Belajar-Kampus Merdeka adalah: 1) Mestinya menyesuaikan ulang kurikulum agar berbasis MBKM yang menyiapkan lulusan untuk ke dunia kerja dan dunia usaha 2) Singkatnya waktu penyusunan kurikulum MBKM Prodi yang diberikan karena kurikulum disusun diawal semester gasal tahun akademik 2020/2021 sehingga program magang industri dimulai saat setengah semester telah berjalan 3) Masih kurangnya minat Mahasiswa karena mestinya membatalkan salah satu mata kuliah pada KRS yang telah diprogram sebelumnya 4) Kesiapan sumber daya dosen masih kurang 5) Masih kurangnya mitra untuk magang dan kewirausahaan 6) Masih kurangnya prodi lain yang menerapkan MBKM yang bersesuain dengan backround program studi. 7) Masih perlunya pengoptimalan sumber daya manusia yaitu kemampuan dosen 8) Masih kurangnya teknologi informasi yang memadai 9) Perlunya menyusun kembali RPP yang sesuai kurikulum MBKM Prodi 10) Padatnya jadwal mengajar dosen 11) Sosialisasi yang dilaksanakan masih perlu lebih maksimal.

Mahasiswa Fakultas Teknik dalam implementasi MBKM terdapat beberapa kendala : 1) Kurangnya pengetahuan mahasiswa terkait kebijakan MBKM secara menyeluruh dan detail; 2) Sosialisasi dan diskusi 
1040 Studi Kebijakan Merdeka Belajar Kampus Merdeka (MBKM) dengan Menggunakan Pendekatan Kuantitatif dan Kualitatif - Ekaterina Setyawati, Ira Mulyawati, Soecahyadi

DOI: https://doi.org/10.31004/edukatif.v4i1.2003

aktif program MBKM dirasa masih kurang ; 3) Teknis dan petunjuk pelaksanaan MBKM di Program Studi belum dapat diakses secara mudah baik oleh mahasiswa maupun oleh dosen. Selian itu pada proses pelaksanaan MBKM berupa kegiatan magang industry dan pertukuaran pelajar antar prodi dalam satu Universitasa ada beberapa mahasiswa tidak mengalami kendala, serta beberapa mahasiswa lain mengalami kendala, kendala yang dialami dari hasil FGD sebagai berikut: 1) Proses pembelajaran yang masih kurang variatif; 2) Masih kurang pahamnya mahasiswa dengan materi Mahasiswaan; 3) keterlambatan penginputan nilai mata kuliah yang di programkan pada pertukaran Mahasiswa; 4) Jaringan yang kurang stabil melihat pembelajaran saat ini daring; 5) Kurang cepatnya ditanggapi oleh dosen dalam pengurusan administrasi; 6) Kurangnya kegiatan saat magang pada kondisi covid; 7) Masih kurangnya mitra dalam program magang sehingga mahasiswa diminta mencari tempat magang sendiri; 8) Kurang massifnya sosialisasi; 9) Pada mahasiswa yang mengikuti program magang masih ada rasa khawatir terkait konversi nilainya.

Focus Group Discussion (FGD) ini bertujuan mengeksplorasi strategi-strategi yang tepat untuk mengatasi berbagai kendala dalam mengimplementasikan kebijakan Merdeka Belajar Kampus Merdeka (MBKM). Hasil dari FGD diantaranya adalah sebagai berikut:

1. Upaya yang dilakukan program studi ataupun dosen agar kendala pelaksanaan dapat dihadapi dan diatasi yaitu pada penyusunan kurikulum dengan kerja sama dosen-dosen kurikulum Merdeka Belajar Kampus Merdeka (MBKM) prodi segera tersusun, sebaiknya persiapan pelaksanaan program dilaksanakan diawal agar maksimal,

2. Perlunya peningkatan infrastruktur, perlu peningkatan prodi yang melaksanakan Merdeka Belajar Kampus Merdeka (MBKM) perluasan mitra ke universitas lain, peningkatan sumber daya serta perlunya memperbanyak MoU ke perusahaan dan kantor untuk pelaksanaan magang dan program kewirausahaan Merdeka Belajar Kampus Merdeka (MBKM).

3. Perlu adanya peningkatan SDM terutama dosen harus siap untuk menjadi dosen yang inovatif, kreatif, fasilitator untuk program MBKM.

4. Perlu adanya dukungan sarana, prasarana dan financial yang memadai baik dari Pemerintah mauun perguruan Tinggi itu sendiri demi mensuskseskan impelementasi program Merdeka Belajar Kampus Merdeka (MBKM)

5. Pada setiap Prodi yang ada di Fakultas Teknik Universitas Sahid Jakarta kendala yang dihadapi dalam pelaksanaan kebijakan Merdeka Belajar Kampus Merdeka (MBKM) adalah sementara menyusun modul digital yang mudah diakses untuk pembelajaran yang akan digunakan sebagai panduan mahasiswa, terkait jadwal mengajar dosen yang padat dosen mengupayakan komunikasi dengan mitra mengajar, prodi telah merencanakan untuk melaksanakaan pelatihan khusus untuk dosen, untuk memassifkan sosialisasi prodi berupaya untuk sosialisasi berikutnya dilaksanakan secara bertahap.

6. Perlu melakukan sosialisasi dan diskusi aktif secara berkala melalui semua media, baik dilakukan oleh Kemendikbud Ristek, Perguruan tingi, Fakultas dan Program studi . Media yang digunakan harus dapat dijangkau oleh mahasiswa yang tidak memiliki akses internet.

7. Upaya yang dilakukan oleh mahasiswa adalah mencari jaringan yang stabil, memperbanyak bertanya kepada mahasiswa di prodi yang ditempati pertukaran Mahasiswa, belajar mandiri melalui internet, serta mengkomunikasikan, mengkomunikasikan terkait penginputan nilai.

Keterbatasan temuan pada penelitian ini dari program studi ternyata perlu melakukan sosialisasi dan diskusi aktif secara berkala melalui berbagai media baik dilakukan oleh Kemendikbud Ristek, Perguruan tingi, Fakultas dan Program studi. Sosialisasi dan diskusi aktif harus menjangkau mahasiswa yang memiliki keterbatasan untuk mengakses informasi secara online. Kemudian, perlu adanya unit khusus di tingkat Universitas untuk melayani mahasiswa jika ada kendala dalam menerapkan program MBKM. Selanjutnya, Perlu adanya panduan petunjuk Teknis dan petunjuk pelaksanaan MBKM di Program Studi yang dapat diakses secara mudah baik oleh mahasiswa maupun oleh dosen. 
1041 Studi Kebijakan Merdeka Belajar Kampus Merdeka (MBKM) dengan Menggunakan Pendekatan Kuantitatif dan Kualitatif - Ekaterina Setyawati, Ira Mulyawati, Soecahyadi

DOI: https://doi.org/10.31004/edukatif.v4i1.2003

Makna penelitian Merdeka Belajar Kampus Merdeka (MBKM) bagi mahasiswa fakultas teknik adalah mahasiswa menjadi peka terhadap perubahan yang cepat terkait ilmu pengetahuan dan teknologi serta perubahan social sehingga mahasiswa bisa mempersiapkan diri dan untuk bisa bersaing di dunia kerja, mahasiswa menjadi lebih percaya diri karena memiliki pengelaman praktek dilapangan bukan hanya sekedar teori.

\section{KESIMPULAN}

Kesimpulan dari penelitian ini diantaranya adalah pengetahuan mahasiswa mengenai adanya kebijakan program MBKM sudah sangat baik, tetapi untuk pengetahuan mahasiswa secara detail mengenai program MBKM masih pada rentang rendah dan cukup baik. Kemudian, kesiapan mahasiswa untuk menjadi bagian dalam kegiatan MBKM sudah cukup baik, kendati demikian perlu menjadi perhatian untuk mahasiswa yang sudah mempersiapkan dan bingung bagaimana memulai keiikutsertaannya pada program MBKM dan penilaian mahasiswa mengenai manfaat program MBKM sudah sangat baik. Beberapa rekomendasi strategistrategi untuk mengatasi berbagai kendala dalam mengimplementasikan kebijakan MBKM, diantaranya perlu melakukan sosialisasi secara berkala melalui media-media online, baik dilakukan oleh Kemendikbud Ristek, Perguruan tingi, Fakultas dan Program studi. Kemudian, perlu melakukan diskusi aktif secara berkala baik dilakukan oleh Kemendikbud Ristek, Perguruan tingi, Fakultas dan Program studi .Selanjutnya, perlu adanya unit khusus di tingkat Universitas untuk melayani mahasiswa jika ada kendalan dalam menerapkan program MBKM dan yang terakhir perlu adanya panduan petunjuk Teknis dan petunjuk pelaksanaan MBKM di Program Studi, sementara ini di Universitas Sahid baru tersedian pedoman di tingkat Universitas.

\section{UCAPAN TERIMA KASIH}

Terima kasih kami ucapkan yang sebesar-besarnya atas dukungan dan hibah pendanaan dari Ditjen Dikti Kemendikbud Ristek pada program MBKM di Universitas Sahid Jakarta.

\section{DAFTAR PUSTAKA}

Afiyanti, Y. (2008). Focus Group Discussion (Diskusi Kelompok Terfokus) sebagai Metode Pengumpulan Data Penelitian Kualitatif. Jurnal Keperawatan Indonesia, 12(1), 58-62. http://www.jki.ui.ac.id/index.php/jki/article/view/201

Asiah, N. (2021). Implementasi Kebijakan Merdeka Belajar-Kampus Merdeka (Studi pada Fakultas Ilmu Sosial dan Hukum Universitas Negeri Makassar).

Baert, B. S., Neyt, B., Siedler, T., Tobback, I., \& Verhaest, D. (2021). Student internships and employment opportunities after graduation: A field experiment. Economics of Education Review, 83. https://doi.org/10.1016/J.ECONEDUREV.2021.102141

Denny Pareira Meke, K., Barry Astro, R., Daud, M. H., Studi Pendidikan Matematika, P., \& Studi Pendidikan Fisika, P. (2022). Dampak Kebijakan Merdeka Belajar Kampus Merdeka (MBKM) pada Perguruan Tinggi Swasta di Indonesia. Edukatif: Jurnal Ilmu Pendidikan, 4(1), 675-685. https://doi.org/10.31004/edukatif.v4i1.1940

Fatmawati, E. (2021). Implementasi Milestone Jangka Pendek Dalam Strategi Tata Kelola Perpustakaan Universitas Diponegoro Pada Masa Pandemi Covid-19.

Fuadi, T. M., \& Aswita, D. (2021). Merdeka Belajar Kampus Merdeka (MBKM) : Bagaimana Penerapan dan Kedala yang Dihadapi Oleh Perguruan Tinggi Swasta di Aceh. Jurnal Dedikasi Pendidikan, 5(2), 603 614. http://103.52.61.43/index.php/dedikasi/article/view/2051

Gibah (Internal Initiative Movement Program For Grants): A Viable Implementation of MBKM Program in Science Major At Universitas Kristen Maranatha. (n.d.). European Journal of Humanities and Educational Advancements. 
1042 Studi Kebijakan Merdeka Belajar Kampus Merdeka (MBKM) dengan Menggunakan Pendekatan Kuantitatif dan Kualitatif-Ekaterina Setyawati, Ira Mulyawati, Soecahyadi

DOI: https://doi.org/10.31004/edukatif.v4i1.2003

Hasil, J., Dan, P., Kepustakaan Di Bidang, K., Pembelajaran, D., Kamalia, P. U., \& Andriansyah, E. H. (2021). Independent Learning-Independent Campus (MBKM) in Students' Perception. Jurnal Kependidikan: Jurnal Hasil Penelitian Dan Kajian Kepustakaan Di Bidang Pendidikan, Pengajaran Dan Pembelajaran, 7(4), 857-867. https://doi.org/10.33394/JK.V7I4.4031

Kodrat, D., \& Kodrat, D. (2021). Industrial Mindset of Education in Merdeka Belajar Kampus Merdeka (MBKM) Policy. Jurnal Kajian Peradaban Islam, 4(1), 9-14. https://doi.org/10.47076/jkpis.v4i1.60

Laga, Y., Nona, R. V., Langga, L., \& Jamu, M. E. (2022). Persepsi Mahasiswa Terhadap Kebijakan Merdeka Belajar Kampus Merdeka (MBKM). Edukatif: Jurnal Ilmu Pendidikan, 4(1), 699-706. https://doi.org/10.31004/EDUKATIF.V4I1.1951

Nona, R. V., Banda, F. L., Leha, E., Supardi, P. N., Meke, K. D. P., \& Suryani, L. (2022). Persepsi Dosen Universitas Flores Terhadap Program Merdeka Belajar Kampus Merdek. Edukatif: Jurnal Ilmu Pendidikan, 4(1), 771-780. https://doi.org/10.31004/EDUKATIF.V4I1.1976

Pembelajaran, D., Direktorat, K., Pendidikan, J., Pendidikan, T. K., \& Kebudayaan, D. (n.d.). Panduan Program Bantuan Kerja Sama Kurikulum dan Implementasi Merdeka Belajar-Kampus Merdeka.

Puspitasari, R., \& Nugroho, R. (2021). Implementasi Kebijakan Merdeka Belajar Kampus Merdeka FISIP UPN Veteran Jawa Timur. Dinamika Governance : Jurnal Ilmu Administrasi Negara, 11(2). https://doi.org/10.33005/JDG.V11I2.2539

Rosmiati, R., Putra, I., \& Nasori, A. (2021). Pengukuran Mutu Pembelajaran di FKIP UNJA dalam Upaya Membangun Generasi Economic Citizen yang Mengelaborasi Program MBKBM Kemendikbud. Edukatif: Jurnal Ilmu Pendidikan, 3(6), 5256-5264. https://doi.org/10.31004/EDUKATIF.V3I6.1356

Saehana, S., Ali, M., Darsikin, D., Nurgan, N., \& Ratnaningtyas, D. I. (2021). Pelatihan Penggunaan Learning Management System (LMS) bagi Guru Sebagai Mitra Asistensi Mengajar Program MBKM Prodi Pendidikan Fisika FKIP Universitas Tadulako. Bubungan Tinggi: Jurnal Pengabdian Masyarakat, 3(4), 441-446. https://doi.org/10.20527/BTJPM.V3I4.4333

Septiani, A., \& Kejora, M. T. B. (2021). Tingkat Aktivitas Belajar Siswa Pada Pembelajaran Online Pendidikan Agama Islam di Masa Pandemi Covid-19. Edukatif: Jurnal Ilmu Pendidikan, 3(5), 2594 2606. https://doi.org/10.31004/edukatif.v3i5.914

Sopiansyah, D., Masruroh, S., Zaqiah, Q. Y., \& Erihadiana, M. (2022). Konsep dan Implementasi Kurikulum MBKM (Merdeka Belajar Kampus Merdeka). Reslaj : Religion Education Social Laa Roiba Journal, 4(1), 34-41. https://doi.org/10.47467/RESLAJ.V4I1.458

Sulistiyani, E., Khamida, K., Soleha, U., Amalia, R., Hartatik, S., Putra, R. S., Budiarti, R. P., \& Andini, A. (2022). Implementasi Merdeka Belajar Kampus Merdeka (MBKM) pada Fakultas Kesehatan dan Non Kesehatan. Edukatif: Jurnal Ilmu Pendidikan, 4(1), 686-698. https://doi.org/10.31004/edukatif.v4i1.1943

View of Dampak Kebijakan MBKM Pada Kesiapan Sumber Daya Manusia dan Fasilitas Fakultas Hukum Usahid Jakarta. (n.d.). Retrieved January 6, 2022, from

https://jurnal.upgriplk.ac.id/index.php/morality/article/view/235/156

View of Penguatan Pemahaman dan Orientasi Kurikulum Kampus Merdeka dalam Menyambut Merdeka Belajar-Kampus Merdeka. (n.d.). Retrieved January 6, 2022, from https://mathdidactic.stkipbjm.ac.id/index.php/abdimas/article/view/1361/710

View of Rancangan Solusi Pengelolaan Sampah dengan Konsep Focus Group Discussion (FGD) Penta Helix di Kabupaten Garut. (n.d.). Retrieved January 6, 2022, from http://jess.ppj.unp.ac.id/index.php/JESS/article/view/270/145

Widiyati, W. (2019). Focus Group Discussion (FGD) untuk Meningkatkan Aktivitas dan Hasil Belajar Kompetensi Ketenagakerjaan Pe-serta Didik di SMP N 7 Purworejo. Indonesian Journal of History Education, 7(2), 146-153. https://doi.org/10.15294/IJHE.V7I2.36432 